\title{
Potential Change of Soil Microbial Diversity in Anticipated Atmospheric-CO2 Elevation Triggers Rhizosphere Activation: A Meta-analysis.
}

Pratap Bhattacharyya ( $\sim$ pratap162001@gmail.com )

ICAR-NRRI https://orcid.org/0000-0003-4007-4357

Eldho Varghese

ICAR-NRRI

Pradeep Kumar Dash

ICAR-NRRI

Soumya Ranjan Padhy

ICAR-NRRI

Priyabrata Santra

ICAR-NRRI

Trilochan Mohapatra

ICAR-NRRI

\section{Research Article}

Keywords: Climate change, Elevated CO2, Microbial diversity, Meta-analysis, Crop yield

Posted Date: November 15th, 2021

DOI: https://doi.org/10.21203/rs.3.rs-1062785/v1

License: (c) (1) This work is licensed under a Creative Commons Attribution 4.0 International License. Read Full License 


\section{Abstract}

One of the key challenges in present time to meet out growing global food demand without damaging environment under constant threats of climate-extremes. Enhancement of nutrient use efficiency and build up intrinsic system tolerance through soil microbial manipulation has gained significant international support to address this challenge. Impact of elevated carbon dioxide $\left(\mathrm{CO}_{2}\right)$ on soil microbial diversities both at present and future climatic scenario in spatial and temporal scale is highly debated with respect to its effects on soil functioning, nutrients dynamics and crop productivity and its practical consequences on resource conservation and food security. We conducted a meta-analysis on global database using 572 observations from 202 studies to investigate the effects of elevated $\mathrm{CO}_{2}$ on soil microbial biomass carbon (MBC), yield and structural (soil microbial populations) and functional (soil enzymatic activities) diversities across 22 countries and 108 crop species. Overall, our results revealed that $\mathrm{MBC}$ and functional diversity increases with elevated atmospheric- $\mathrm{CO}_{2}$ irrespective of temperature zone and crop type. However, data trends showed structural diversity has been gradually adapted under elevated $\mathrm{CO}_{2}$ across the region over decadal scale. Anticipated elevation of atmospheric $\mathrm{CO}_{2}$ increase rhizospheric activities and could make soil more input demanding and more so in temperate region. Therefore, to fetch the benefits of $\mathrm{CO}_{2}$ fertilization and to meet out the higher demand both plant and soil (microbes), real time judicious nutrient supply is necessary; otherwise, soil priming, loss of fixed soil carbon reserve and land degradation might threat the future food security.

\section{Introduction}

To address the issues of yield sustainability and food security under climate change risks, build-up of system resilience with higher resource use efficiency through microbial manipulation is a sustainable approach that harm the environment least. Elevation of atmospheric $\mathrm{CO}_{2}$ level from 273 to 412 ppm (from 1750 to 2020) and mean annual surface temperature from 14 to $14.89^{\circ} \mathrm{C}$ (from 1750 to 2020) are evident due to climate change in last two centuries [1]. Further, atmospheric $\mathrm{CO}_{2}$ concentration is going to be increased @ 1.5 ppm year ${ }^{-1}$ up to 2050 [2, 3] which will affect the crop yield, soil nutrient and water balance and microbial diversities in near future. Soil microbes plays a crucial role in nutrient dynamics $[4,5,6,7]$, soil aggregation $[7,8]$ and yield $[9,10]$. More so, it has higher adaptability under stress $[11,12,13]$ and ability to build up intrinsic system resilience (to drought, salinity, flood, nutrient scarcity) $[14,15]$ and enhance nutrient use efficiency (e.g., N, P, K, Mn etc.) [16, 17].

We know that elevation of atmospheric $\mathrm{CO}_{2}$ influences the above ground and belowground biomass production and carbon (C) allocations. The below ground $\mathrm{C}$ allocation primarily due to higher root exudation, higher availability of labile $C$ as substrates for microbial enrichment and greater microbial activities [18]. The microbial biomass $C$ and soil-enzymatic activities enhances due to elevated $\mathrm{CO}_{2}$ which lead to higher nutrient mobilization, GHGs emissions and soil priming [19]. However, there are contrasting reporting about change in soil microbial diversities due to elevation of $\mathrm{CO}_{2}$ and temperature, particularly population dynamics of bacteria and fungus and their functionality. Manny research group emphasized that there would be no change in microbial diversity as microbes are highly adaptable. Other groups provided evidence regarding shifting of structural as well as functional diversities both in negative and positive directions [19,20,21,22]. The debate is on, but the question is not on the change in the directions of diversities, it is the matter of functioning of crop rhizosphere in anticipated climate change scenarios. Whether the change in microbial functioning in rhizosphere would affect the crop yield, soil health and food security? Whether the nutrient demand would be more for getting the desired yield? Whether our soil would be going to loss for its reserve $\mathrm{C}$ due soil-priming in elevated $\mathrm{CO}_{2}$ condition? 
To answer these questions, we analysed scientific evidence at global scale to assess the impacts of elevated $\mathrm{CO}_{2}$ on soil microbial biomass carbon, microbial diversities (both structural and functional) and yield on spatial and temporal scale.

\section{Materials And Methods}

\section{Data inventories and data base}

A compressive meta-analysis was done on published data in peer reviewed journals and books, representing a significant assessment on this key issue. Because most of the studies on the effect of elevated $\mathrm{CO}_{2}$ on plants were focused on yield, biomass production and photosynthetic efficiencies, not on soil microbial diversities and functionalities; both field and laboratory studies containing tropical and temperate regions, on cereals, horticulture, grassland, and forest crops over last five decades (1970-2020) were included in metadata base. Since, impact of climate change, specifically the effect of elevated $\mathrm{CO}_{2}$ on soil microbial diversities are distinctly depends on temperature, tropical and temperate zones were analysed separately irrespective of types of crops and $\mathrm{CO}_{2}-$ elevation range. To assess, how the effect of elevated $\mathrm{CO}_{2}$ varied across the two temperature zones on temporal scale on plants (agriculture/forest), yield, microbial biomass carbon (MBC) and microbial diversities (structural and functional) including bacterial and fungal population and soil enzymatic activities were grouped based on original data. For comparison, two temperature zones (tropical and temperate), three decadal time scales (1970-1990; $1990-2010 ; 2010-2020)$ and eight $\mathrm{CO}_{2}$ - elevated ranges $(0-10 \% ; 10-20 \% ; 20-30 \% ; 30-40 \% ; 40-50 \% ; 50-60 \% ; 60-70 \%$; $70-80 \%)$ were considered. In total, there were 202 studies covering 22 countries and 108 plants /crops species in the data base.

We exhaustively search the literatures including research articles, books, book chapters that were peer-reviewed for studying the effects of elevated $\mathrm{CO}_{2}$ on crop yields, microbial biomass carbon and structural (bacterial and fungal population) and functional (soil enzymatic activities) soil microbial diversities from 1970 to 2020. Search keywords included elevated $\mathrm{CO}_{2}$, open top chamber, free air $\mathrm{CO}_{2}$ enrichment (FACE), climate change, crop yield, microbial biomass carbon, bacterial population, fungal population and soil enzymatic activities in the article, title, abstract and keywords. Not reviewed and non-English language publications were discarded. These searches produce around 2000 publications. Then the publications were screened based on following criteria; a) field and laboratory experiments of elevated $\mathrm{CO}_{2}$ on either yield or $\mathrm{MBC}$ or enzymatic activities or bacterial and fungal population or any of the two must be compared with ambient (reference/ control) condition; b) cereals (particularly grain) and forestry crops were both from temperate and tropical region were considered; $c$ ) in field experiment yield was stated; d) location/ latitude-longitude of the experiment reported; e) management options and replications mentioned; f) different experiments even at same location at different times were also included. As this type of futuristic study are not quite common and there are limitations of crop phenology (height, duration), we tried to gather relevant published data for meta-analysis. We also rejected confusing and unclear results and methods according to our knowledge and more emphasis were goes to $\mathrm{C}_{3}$ crops (cereals) as those are directly related to food security of resource poor countries. Specific attention was given to reject and avoid the duplicate data (e.g., different experiment reported similar kind of data in different perspective). A portion of our researched publication on climate change/ elevated $\mathrm{CO}_{2}$ experiments were avoided due to absence of control treatment that did not satisfy our criteria. 
Contain cases where specific latitude-longitude were not provided, we extracted those from google earth-apps with the help of location name/ experimental station name. Vector map in the form of point shape file of 86 locations of the climate change/elevated $\mathrm{CO}_{2}$ experiments are prepared and shown as bubble plot over the world map using ArcGIS (Figure 1). Greater the size of bubble in the plot indicates higher number of experiments conducted on that location. Percent change of different parameter due to elevation of $\mathrm{CO}_{2}$ (over ambient/ control) in different research finding were estimated/ analysed where directly not given in publication. In certain places where data were only given in figures or graphs, values were extracted through plot digitizer (http://plotdigitizer.source.net/). Tropical and temperate zone were classified based on generalized climate classification scheme.

Nutrient and water management practices followed were recorded in each study and presented in basic data base (Supplementary Table 1) as binary values (i.e., year category (3): 1970-1990; 1990-2010; 2010-2020); spatial scale (2) (region category: tropical; temperate) and $\mathrm{CO}_{2}$ elevation range on percentage basis (8) (0-10\%, 10-20\%, 20-30\%, $30-40 \%, 40-50 \%, 50-60 \%, 60-70 \%, 70-80 \%)$.

\section{Metadata analysis}

The classified data were subjected to one way analysis of variance (ANOVA) and correlation analysis using PROC GLM and PROC CORR of SAS (SAS institute, Cary, NC, USA), respectively to assess significance of change in yield, $\mathrm{MBC}, \mathrm{MDC}, \mathrm{BP}, \mathrm{FP}$, and enzymatic activities with respect to spatial changes, temporal changes and with changes in $\mathrm{CO}_{2}$ levels. The summary statistic (mean, quartiles, minimum, maximum, and extreme observations/probable outliers) was presented using the box-and-whiskers plots of measurements along with the F-value and Prob >F. Significance among the mean values were assessed at $p<0.05$.

\section{Result}

\section{Impact $\mathrm{CO}_{2}$-elevation range on microbial diversities}

The yield increase was found maximum with $40-50 \% \mathrm{CO}_{2}$-elevation; however, magnitudes of increase were higher at $60-70$ and $70-80 \% \mathrm{CO}_{2}$-elevation over ambient. The highest $\mathrm{MBC}$ was reported for the $\mathrm{CO}_{2}$-elevation range of 50 $60 \%$ over ambient (Figure 2). However, highest increase of MDC was noticed at $30-40 \% \mathrm{CO}_{2}$ elevation. Soil enzymatic activities were affected both positively and negatively. Negative effects were found maximum at $40-50 \%$ $\mathrm{CO}_{2}$ elevation over ambient (Table 1, Figure 2). Correlation study revealed that percent increase of microbial biomass carbon and $\mathrm{MDC}$ were positively correlated with elevated $\mathrm{CO}_{2}$. Minimum correlation was found in case of increase of fungal population to $\mathrm{CO}_{2}$ elevation (Table 1). 
Table 1

Correlation study of percentage increase $\mathrm{CO}_{2}$ with percentage increase of yield, and microbial diversities.

\begin{tabular}{|c|c|c|c|c|c|c|c|}
\hline $\begin{array}{l}\text { Dependent } \\
\text { variable }\end{array}$ & $\begin{array}{l}\text { Independent } \\
\text { variable }\end{array}$ & $\begin{array}{l}\% \\
\text { Increase } \\
\text { Yield }\end{array}$ & $\begin{array}{l}\% \\
\text { Increase } \\
\text { MBC }\end{array}$ & $\begin{array}{l}\% \\
\text { Increase } \\
\text { MDC }\end{array}$ & $\begin{array}{l}\% \\
\text { Increase } \\
\text { BP }\end{array}$ & $\begin{array}{l}\% \\
\text { Increase } \\
\text { FP }\end{array}$ & $\begin{array}{l}\text { \% Increase } \\
\text { Enzyme }\end{array}$ \\
\hline \multirow[t]{3}{*}{$\begin{array}{l}\% \text { Increase } \\
\text { CO2 }\end{array}$} & $\begin{array}{l}\text { Pearson } \\
\text { Correlation } \\
\text { Coefficient }\end{array}$ & 0.092 & 0.584 & 0.145 & -0.095 & 0.007 & -0.134 \\
\hline & $\begin{array}{l}\text { Prob }>|\mathrm{r}| \text { under } \mathrm{HO}: \\
\text { Rho }=0\end{array}$ & 0.392 & 0.561 & 0.518 & 0.604 & 0.969 & 0.389 \\
\hline & $\begin{array}{l}\text { Number of } \\
\text { Observation }\end{array}$ & 87 & 101 & 22 & 32 & 29 & 43 \\
\hline
\end{tabular}

[Note: microbial biomass carbon (MBC), microbial diversity community (MDC), bacterial population (BP), fungal population (FP) and soil enzymatic activity].

\section{Temporal variation of impact elevated $\mathrm{CO}_{2}$ on microbial diversities}

Critical analysis revealed that percentage increase of yield and variation during 1970-90 was higher followed by 1990-2010 and 2010-2020. Correlation analysis revealed that the percentage increase in $\mathrm{CO}_{2}$ have a significant positive correlation with percentage increase in MBC during 1990-2010 (Figure 3). Our result revealed that the impact of elevated $\mathrm{CO}_{2}$ on percentage of total microbial structural diversity (MDC) (including bacteria, fungi, actinomycetes, archaea) change in decadal time frame. Less variability and relatively lower increase of percent MDC in last decades compared to previous one indicates gradual increase of adaptability of microbial communities towards climate change (Table 2). The increase was higher during 1990-2010 compared to 20102020. The temporal change was not significant except for soil enzymatic activities with maximum in temperate region (Figure 3). 
Table 2

Correlation study of percentage increase $\mathrm{CO}_{2}$ with percentage increase of yield, and microbial diversities in respect to temporal scale (1970-1989; 1990-1999; 2010-2020).

\begin{tabular}{|c|c|c|c|c|c|c|c|c|}
\hline $\begin{array}{l}\text { Dependent } \\
\text { variable }\end{array}$ & Year & $\begin{array}{l}\text { Independent } \\
\text { variable }\end{array}$ & $\begin{array}{l}\% \\
\text { Increase } \\
\text { Yield }\end{array}$ & $\begin{array}{l}\% \\
\text { Increase } \\
\text { MBC }\end{array}$ & $\begin{array}{l}\% \\
\text { Increase } \\
\text { MDC }\end{array}$ & $\begin{array}{l}\% \\
\text { Increase } \\
\text { BP }\end{array}$ & $\begin{array}{l}\% \\
\text { Increase } \\
\text { FP }\end{array}$ & $\begin{array}{l}\% \\
\text { Increase } \\
\text { Enzyme }\end{array}$ \\
\hline \multirow[t]{9}{*}{$\begin{array}{l}\text { Percentage } \\
\text { Increase } \\
\mathrm{CO}_{2}\end{array}$} & \multirow[t]{3}{*}{$\begin{array}{l}1970- \\
1989\end{array}$} & $\begin{array}{l}\text { Pearson } \\
\text { Correlation } \\
\text { Coefficient }\end{array}$ & 0.090 & - & - & - & - & - \\
\hline & & $\begin{array}{l}\text { Prob > }|r| \text { under } \\
\text { HO: } \text { Rho }=0\end{array}$ & 0.802 & - & - & - & - & - \\
\hline & & $\begin{array}{l}\text { Number of } \\
\text { Observation }\end{array}$ & 10 & 0 & 0 & 0 & 0 & 0 \\
\hline & \multirow[t]{3}{*}{$\begin{array}{l}1990- \\
1999\end{array}$} & $\begin{array}{l}\text { Pearson } \\
\text { Correlation } \\
\text { Coefficient }\end{array}$ & 0.026 & 0.269 & -0.385 & 0.135 & -0.112 & -0.035 \\
\hline & & $\begin{array}{l}\text { Prob }>|r| \text { under } \\
\text { HO: Rho }=0\end{array}$ & 0.854 & 0.026 & 0.271 & 0.618 & 0.668 & 0.879 \\
\hline & & $\begin{array}{l}\text { Number of } \\
\text { Observation }\end{array}$ & 54 & 68 & 10 & 16 & 17 & 21 \\
\hline & \multirow[t]{3}{*}{$\begin{array}{l}2010- \\
2020\end{array}$} & $\begin{array}{l}\text { Pearson } \\
\text { Correlation } \\
\text { Coefficient }\end{array}$ & -0.266 & -0.058 & 0.418 & -0.208 & 0.196 & 0.113 \\
\hline & & $\begin{array}{l}\text { Prob > }|r| \text { under } \\
\text { HO: } \text { Rho }=0\end{array}$ & 0.219 & 0.747 & 0.175 & 0.439 & 0.539 & 0.615 \\
\hline & & $\begin{array}{l}\text { Number of } \\
\text { Observation }\end{array}$ & 23 & 33 & 12 & 16 & 12 & 22 \\
\hline
\end{tabular}

\section{Spatial variation of impact elevated $\mathrm{CO}_{2}$ on microbial diversities}

We analysed data from hundreds field (198 numbers), and laboratory (4 numbers) trials across 22 countries and 108 crop species (Extended data, supplementary S 1), showed elevated $\mathrm{CO}_{2}$ significantly increased the yield by 26$35 \%$ under temperate and tropical region. Yet average effect of elevated $\mathrm{CO}_{2}$ on yield in respect to region (tropical and temperate) were not found significant although more variation noticed in temperate region. Spatial variability was significantly evident $(\mathrm{p}<0.05)$ for $\mathrm{MBC}$, bacterial population (BP) and soil enzymatic activities with highest in tropical region due to elevation of $\mathrm{CO}_{2}$ (10 to $80 \%$ over ambient) (Table 3, Figure 4). 
Table 3

Correlation study of percentage increase $\mathrm{CO}_{2}$ with percentage increase of yield, and microbial diversities in respect to tropical and temperate region.

\begin{tabular}{|c|c|c|c|c|c|c|c|c|}
\hline $\begin{array}{l}\text { Dependent } \\
\text { variable }\end{array}$ & Region & $\begin{array}{l}\text { Independent } \\
\text { variable }\end{array}$ & $\begin{array}{l}\% \\
\text { Increase } \\
\text { Yield }\end{array}$ & $\begin{array}{l}\% \\
\text { Increase } \\
\text { MBC }\end{array}$ & $\begin{array}{l}\% \\
\text { Increase } \\
\text { MDC }\end{array}$ & $\begin{array}{l}\% \\
\text { Increase } \\
\text { BP }\end{array}$ & $\begin{array}{l}\% \\
\text { Increase } \\
\text { FP }\end{array}$ & $\begin{array}{l}\% \\
\text { Increase } \\
\text { Enzyme }\end{array}$ \\
\hline \multirow[t]{6}{*}{$\begin{array}{l}\% \text { Increase } \\
\mathrm{CO}_{2}\end{array}$} & \multirow[t]{3}{*}{ Tropical } & $\begin{array}{l}\text { Pearson } \\
\text { Correlation } \\
\text { Coefficient }\end{array}$ & -0.382 & 0.213 & - & 0.052 & . & 0.273 \\
\hline & & $\begin{array}{l}\text { Prob > |r| } \\
\text { under HO: } \\
\text { Rho=0 }\end{array}$ & 0.398 & 0.466 & - & 0.948 & . & 0.326 \\
\hline & & $\begin{array}{l}\text { Number of } \\
\text { Observation }\end{array}$ & 7 & 14 & 1 & 4 & 0 & 15 \\
\hline & \multirow[t]{3}{*}{ Temperate } & $\begin{array}{l}\text { Pearson } \\
\text { Correlation } \\
\text { Coefficient }\end{array}$ & 0.079 & 0.187 & 0.138 & 0.137 & 0.007 & -0.098 \\
\hline & & $\begin{array}{l}\text { Prob > |r| } \\
\text { under HO: } \\
\text { Rho=0 }\end{array}$ & 0.483 & 0.082 & 0.551 & 0.488 & 0.969 & 0.621 \\
\hline & & $\begin{array}{l}\text { Number of } \\
\text { Observation }\end{array}$ & 80 & 87 & 21 & 28 & 29 & 28 \\
\hline
\end{tabular}

[Note: microbial biomass carbon (MBC), microbial diversity community (MDC), bacterial population (BP), fungal population (FP) and soil enzymatic activity].

\section{Discussions}

Overall, elevated $\mathrm{CO}_{2}$ significantly affects the yield irrespective of region and decadal slabs. Those higher yields corresponded to higher photosynthetic efficiency $[10,19,23]$ of $C_{3}$ crop led to higher biomass production and carbon (C) accumulation [19,24]. Further, the magnitude of percentage yield-increase and variation over decades reduces gradually, indicated greater adaptation of plant communities to elevated $\mathrm{CO}_{2}[10,11]$ and or also due to technological advancement (i.e., introduction of climate resilient varieties and improved soil-water-plant management practices $[15,25,26]$. However, the crop specific (cereals, forest, grass land, etc.) impacts on yield in our study were masked the temperature zone-effect under elevated $\mathrm{CO}_{2}[27,28,29,30]$. These finding are consistent with smaller data set (572 observations) in which considered both the crop types (both $\mathrm{C}_{3}$ and $\mathrm{C}_{4}$ ) together. In general, we found that cereals (mostly $\mathrm{C}_{3}$ ) were positively affected (83 nos. crops; note presented separately), providing support to our conclusion [31, 32]. However, detrimental consequence due to temperature rise associated with elevation of atmospheric $\mathrm{CO}_{2}$ level is well established particularly in dry season crop in tropics [33, 34].

To sustain global agricultural productivity and limit soil degradation in future climate change scenario (higher atmospheric $\mathrm{CO}_{2}$ concentration), $\mathrm{MBC}$ and functional microbial diversities need to be regulated/managed judiciously $[35,36,37]$. Microbial biomass $C$ found to be most sensitive indicator to rhizospheric functioning under elevated $\mathrm{CO}_{2}$ irrespective of temperature zones and crop types [38, 39, 40,41]. In temperate region, a significant change in the $\mathrm{MBC}$ was reported with respect to percentage increase of atmospheric $\mathrm{CO}_{2}[39,42]$. However, in our 
study, the overall non-significant effects of elevated $\mathrm{CO}_{2}$ on bacterial and fungal population indicated higher structural adaptability of microbial communities (bacterial and fungi) to climate change consequences (elevated atmospheric $\mathrm{CO}_{2}$ ).

In our study, the impact of elevated $\mathrm{CO}_{2}$ on microbial diversities was found more in temperate region than tropical due to relatively higher temperature build up in cooler region (due to $\mathrm{CO}_{2}$-elevation) which triggered microbial activities, soil enzymatic activities and respiration [14, 43, 44, 45, 46]. That means, we have been getting and going to get more functionally active rhizosphere in temperate zone compared to tropics in coming century $[36,47,48]$.

It is often noticed that crop could not response to best management practices as expected due to unprecedented climate related stresses. So, their always exist risk for short to medium-term reduction in crop production possess a barrier for farmers $[49,50]$. Nutrient-water use efficiency causally related to microbial functionality at rhizosphere level. Our results confirm that there would be a change in functional diversity of microbes due to elevation of $\mathrm{CO}_{2}$ (predicted in high certainty of climate change consequences) in root zone of cereals, grass, and forest crops both in tropical and temperate region. So, we are going to get a more active rhizosphere in temperate zone which could increase the availability of nitrogen $(N)$, phosphorus $(P)$, potassium $(K)$, and micro-micronutrients. Obviously, the crops demand of those nutrients would be more to maintain proper C: N/P/S ratios in plant and to produce sustainable yield $[16,17,51,52]$. Therefore, real-time judicious nutrient management (both fertilizer and manure) is necessary in coming future; otherwise, we could loss the $\mathrm{CO}_{2}$-fertilization benefit in one hand and may emit more GHGs to atmosphere causing positive feedback to climate change [2, 34, 35]. As we found significant increase (6$59 \%$ ) in MBC irrespective of crops and temperature zones, we can say that our soil would be hungry to meet the higher demand of microbes. So, if we are not able to supply the demand of nutrients in available form there could be soil-priming $[53,54,55]$. Soil priming could exhaust the reserve of fix-C and in long run could cause soil health deterioration and land degradation $[53,56,57,58]$. Non-significant structural changes of microorganisms due to $\mathrm{CO}_{2}$ elevation indicated greater adoptability of them. So, there are ample possibility that those changes in microbial diversity could provide intrinsic stress (drought, flood, salinity) tolerance to crop. Therefore, intelligent water as well as nutrient management for harnessing the climate change-benefits and saving the resources are in the card. There are positives of $\mathrm{CO}_{2}$-elevation (climate change consequences) both in plant, soil, and microbial context. But the mechanism and interrelationship need to understand properly. As per example, we must give more $\mathrm{C}, \mathrm{N}, \mathrm{P}, \mathrm{K}$ and micronutrient input to soil considering both plant and microbes demands in future; otherwise, there would be soildegradation and crop- productivity deterioration $[59,60]$.

It could not be determined from our study, whether typical biophysical conditions (e.g., soil texture/structure, soilsurface feature, residue-decomposition history etc.) or sub-optimal management practices are the reason for change in yield, $\mathrm{MBC}$, and microbial diversity. Our hypothesis was that the dataset represents a holistic change in MBC, yield, microbial diversity and soil enzymatic activities across the regions and crops. Further, global scale study is needed to identify the combine effect of elevated $\mathrm{CO}_{2}$ and temperature on microbial diversity in specific water regimes.

However, climate change is a global phenomenon but the impacts on soil microbial diversity is typically site specific $[44,46]$. Nevertheless, disproportionate number of world's poor farmers resides in Africa, South-Asia, Saharan-Africa, still struggling with food security are more vulnerable to climate change vagaries, land degradation and yield reduction. Microbial health of soil is the key indicator of soil-health and land degradation. Therefore, 
efforts need to be done for intelligent nutrient and water management through microbial mediated rhizosphere manipulation to make the soil-plant systems more climate smart.

Therefore, our result suggested the integrated microbe-nutrient-water management practices in stressed region to meet current and future production challenges and to fetch beneficial effect of higher rhizosphere activities (higher microbial functioning) in terms of better nutrient availability and C-build up (Figure 5). This is a key finding in respect to the prediction ( $>90 \%$ certainty) that millions of hectares in temperate -Asia, America and Europe are going to fetch benefits from climate change induced- $\mathrm{CO}_{2}$ fertilization $[9,49,61,62]$, still, if microbial mediated crop management is to be successful to cope up climate change vagaries and utilize the beneficial effect of $\mathrm{CO}_{2}$ fertilization for sustaining crop productivity, it should be adjusted to local situations through an innovative coordinated approach that is sensitive to farmers preference, market-choice, and facilities available [30, 46]. Therefore, we should give more focus to utilize and manipulate the functional aspect of microbes related to nutrient dynamics, water availability, C-sequestration for farming as short to mid-term strategies to climate change adaptation. Projected climate changes in respect to temperature and precipitation causing frequent drought/ flood, pest virulence, water scarcity is expected in critical agricultural hub of the world $[14,15]$. Depending on the type, intensity and severity of those climate change-vagaries, critical adaptation measures would be necessary to sustain global agricultural production at a desired level; the microbial mediated rhizosphere-manipulation could provide sustainable solution for improving water-nutrient use efficiencies, greenhouse gasses (GHGs) emissionmitigation and to impart intrinsic tolerance to the system (soil-plant-atmosphere continuum) to climate change threats $[63,64,65]$.

\section{Conclusion}

Clearly, there are enhanced functional diversity and biomass carbon of microbes under elevated $\mathrm{CO}_{2}$ which have both economic and environmental consequences. Future (coming 2-4 decades) crop-soil systems would require more nutrients, water, and carbon to produce sustainable yield; failed to provide that soil-priming and land degradation would be the risk. Climate change-land degradation-soil microbial health is in a vicious cycle. Unless we break the cycles, starting from microbial manipulation, positive feedback to climate change would continue. Hence, conscious efforts to improve real-time nutrient-water management in crops in response to change in microbial functional diversity in near future could "backfire" and promote negative feedback to climate change.

\section{Declarations}

Conflict of Interest: The authors declare no competing interest.

\section{Acknowledgements:}

Authors are also grateful to ICAR-NRRI, DBT, NICRA for their support and guidance. The support of Dr. H Pathak, Dr. D Maiti, Dr. A K Nayak, Dr. A Sarkar and Dr. C K Swain are also duly acknowledged.

Funding Authors are grateful to the ICAR-National Fellow Project for supporting with grant number Agri. Edn. /27/08/NF/2017-HRD; EAP-248.

Conflict of Interest The authors declare no competing interest.

Ethics Approval Not applicable. 
Consent to Participate Not applicable.

Consent for Publication All authors agreed with the publication of this manuscript.

Availability of Data and Material All data during this study are included in this published article and its supplementary information files.

Code availability The PROC GLM and PROC CORR of SAS (SAS institute, Cary, NC, USA) were used for data analysis.

Author Contribution P.B. and T.M. were involved in conceptualizing, editing and language correction of the manuscript. E.V. and P.S. conducted the meta-analysis constructed the spatial distribution map. P.B. and S.R.P. were collected the review paper, prepared the manuscript and analysed the data.

\section{References}

1. Intergovernmental Panel on Climate Change (2018) Global Warming of $1.5^{\circ} \mathrm{C}$ : An IPCC Special Report on the Impacts of Global Warming of $1.5^{\circ} \mathrm{C}$ Above Pre-Industrial Levels and Related Global Greenhouse Gas Emission Pathways, in the Context of Strengthening the Global Response to the Threat of Climate Change, Sustainable Development, and Efforts to Eradicate Poverty. Intergovernmental Panel on Climate Change.

2. Hoegh-Guldberg O, Jacob D, Taylor M, Bolaños TG, Bindi M, Brown S, Camilloni IA, Diedhiou A, Djalante R, Ebi K, Engelbrecht $F$ (2019) The human imperative of stabilizing global climate change at $1.5 \mathrm{C}$. Science 365(6459).

3. Robinson SA (2020) Climate change adaptation in SIDS: A systematic review of the literature pre and post the IPCC Fifth Assessment Report. Wiley Interdisciplinary Reviews: Climate Change 11(4):e653.

4. Six J, Carpentier A, van Kessel C, Merckx R, Harris D, Horwath WR, Lüscher A (2001) Impact of elevated $\mathrm{CO}_{2}$ on soil organic matter dynamics as related to changes in aggregate turnover and residue quality. Plant and Soil 234(1):27-36.

5. Castro HF, Classen AT, Austin EE, Norby RJ, Schadt CW (2010) Soil microbial community responses to multiple experimental climate change drivers. Appl Environ Microbiol 76(4):999-1007.

6. Shade A, Peter H, Allison SD, Baho D, Berga M, Bürgmann H, Huber DH, Langenheder S, Lennon JT, Martiny JB, Matulich KL (2012) Fundamentals of microbial community resistance and resilience. Frontiers in Microbiol 3:417.

7. Hungate BA, Van GROENIGEN KJ, Six J, Jastrow JD, Luo Y, De GRAAFF MA, Osenberg CW (2009) Assessing the effect of elevated carbon dioxide on soil carbon: a comparison of four meta-analyses. Global Change Biol 15(8):2020-2034.

8. Eviner VT, Chapin FS (2002) The influence of plant species, fertilization and elevated $\mathrm{CO}_{2}$ on soil aggregate stability. Plant and Soil 246(2):211-219.

9. Van Oort PA, Zwart SJ (2018) Impacts of climate change on rice production in Africa and causes of simulated yield changes. Global Change Biol 24(3):1029-1045. 
10. Raj A, Chakrabarti B, Pathak H, Singh SD, Mina U, Purakayastha TJ (2019) Growth, yield and nitrogen uptake in rice crop grown under elevated carbon dioxide and different doses of nitrogen fertilizer.

11. Schlüter L, Lohbeck KT, Gutowska MA, Gröger JP, Riebesell U, Reusch TB (2014) Adaptation of a globally important coccolithophore to ocean warming and acidification. Nature Climate Change 4(11):1024-1030.

12. Riebesell U, Gattuso JP (2015) Lessons learned from ocean acidification research. Nature Climate Change 5(1):12-14.

13. Hutchins DA, Fu F (2017) Microorganisms and ocean global change. Nature Microbiol 2(6):1-11.

14. Schimel J, Balser TC, Wallenstein M (2007) Microbial stress-response physiology and its implications for ecosystem function. Ecology 88(6):1386-1394.

15. Chaturvedi AK, Bahuguna RN, Shah D, Pal M, Jagadish SK (2017) High temperature stress during flowering and grain filling offsets beneficial impact of elevated $\mathrm{CO}_{2}$ on assimilate partitioning and sink-strength in rice. Scientific Reports 7(1):1-13.

16. Singh BK, Bardgett RD, Smith P, Reay DS (2010) Microorganisms and climate change: terrestrial feedbacks and mitigation options. Nature Reviews Microbiol 8(11):779-790.

17. Bardgett RD, Van Der Putten WH (2014) Belowground biodiversity and ecosystem functioning. Nature 515(7528):505-511.

18. Bhattacharyya P, Roy KS, Neogi S, Chakravorti SP, Behera KS, Das KM, Bardhan S, Rao KS (2012) Effect of longterm application of organic amendment on $\mathrm{C}$ storage in relation to global warming potential and biological activities in tropical flooded soil planted to rice. Nutrient Cycling in Agroecosyst 94(2):273-285.

19. Bhattacharyya P, Roy KS, Neogi S, Manna MC, Adhya TK, Rao KS, Nayak AK (2013) Influence of elevated carbon dioxide and temperature on belowground carbon allocation and enzyme activities in tropical flooded soil planted with rice. Environ Monitoring Assessment 185(10):8659-8671.

20. Hayden HL, Mele PM, Bougoure DS, Allan CY, Norng S, Piceno YM, Brodie EL, DeSantis TZ, Andersen GL, Williams AL, Hovenden MJ (2012) Changes in the microbial community structure of bacteria, archaea and fungi in response to elevated $\mathrm{CO} 2$ and warming in an A ustralian native grassland soil. Environ Microbiol 14(12):30813096.

21. Lee SH, Kim SY, Kang H (2012) Effects of elevated $\mathrm{CO}_{2}$ on communities of denitrifying bacteria and methanogens in a temperate marsh microcosm. Microbial Ecol 64(2):485-498.

22. Liu Y, Li M, Zheng J, Li L, Zhang X, Zheng J, Pan G, Yu X, Wang J (2014) Short-term responses of microbial community and functioning to experimental $\mathrm{CO}_{2}$ enrichment and warming in a Chinese paddy field. Soil Biol Biochem 77:58-68.

23. Ainsworth EA, Long SP (2021) 30 years of free-air carbon dioxide enrichment (FACE): What have we learned about future crop productivity and its potential for adaptation? Glob Change Biol 27(1):27-49. 
24. Evans RD, Koyama A, Sonderegger DL, Charlet TN, Newingham BA, Fenstermaker LF, Nowak RS (2014) Greater ecosystem carbon in the Mojave Desert after ten years exposure to elevated $\mathrm{CO}_{2}$. Nature Climate Change 4(5):394397.

25. Drake JE, Gallet-Budynek A, Hofmockel KS, Bernhardt ES, Billings SA, Jackson RB, Finzi AC (2011) Increases in the flux of carbon belowground stimulate nitrogen uptake and sustain the long-term enhancement of forest productivity under elevated $\mathrm{CO}_{2}$. Ecol Letters 14(4):349-357.

26. Hepburn C, Adlen E, Beddington J, Carter EA, Fuss S, Mac Dowell N, Williams CK (2019) The technological and economic prospects for $\mathrm{CO}_{2}$ utilization and removal. Nature 575(7781):87-97.

27. Joergensen RG (2010) Organic matter and micro-organisms in tropical soils. In Soil biology and agriculture in the tropics (pp. 17-44). Springer, Berlin, Heidelberg.

28. Hartley IP, Garnett MH, Sommerkorn M, Hopkins DW, Fletcher BJ, Sloan VL, Wookey, PA (2012) A potential loss of carbon associated with greater plant growth in the European Arctic. Nature Climate Change 2(12):875-879.

29. Giardina CP, Litton CM, Crow SE, Asner GP (2014) Warming-related increases in soil CO 2 efflux are explained by increased below-ground carbon flux. Nature Climate Change 4(9):822-827.

30. Bradford MA, Wieder WR, Bonan GB, Fierer N, Raymond PA, Crowther TW (2016) Managing uncertainty in soil carbon feedbacks to climate change. Nature Climate Change 6(8):751-758.

31. Broberg MC, Högy P, Feng Z, Pleijel H (2019) Effects of elevated $\mathrm{CO}_{2}$ on wheat yield: non-linear response and relation to site productivity. Agronomy 9(5):243.

32. Ujiie K, Ishimaru K, Hirotsu N, Nagasaka S, Miyakoshi Y, Ota M, Magoshi J (2019) How elevated CO2 affects our nutrition in rice, and how we can deal with it. PloS one, 14(3), e0212840.

33. De GRAAFF, M. A., Van GROENIGEN, K. J., Six, J., Hungate, B., \& van Kessel, C. (2006). Interactions between plant growth and soil nutrient cycling under elevated CO2: a meta-analysis. Global Change Biology, 12(11), 20772091.

34. Dutta H, Dutta A (2016) The microbial aspect of climate change. Energy Ecol Environ 1(4):209-232.

35. Zhou J, Xue K, Xie J, Deng YE, Wu L, Cheng X, Fei S, Deng S, He Z, Van Nostrand JD, Luo Y (2012) Microbial mediation of carbon-cycle feedbacks to climate warming. Nature Climate Change 2(2):106-110.

36. Karhu K, Auffret MD, Dungait JA, Hopkins DW, Prosser JI, Singh BK, Subke JA, Wookey PA, Ågren GI, Sebastia MT, Gouriveau F (2014) Temperature sensitivity of soil respiration rates enhanced by microbial community response. Nature, 513(7516):81-84.

37. Xue S, Yang X, Liu G, Gai L, Zhang C, Ritsema CJ, Geissen V (2017) Effects of elevated CO2 and drought on the microbial biomass and enzymatic activities in the rhizospheres of two grass species in Chinese loess soil. Geoderma 286:25-34.

38. Davidson EA, Janssens IA, Luo Y (2006) On the variability of respiration in terrestrial ecosystems: moving beyond Q10. Global Change Biol 12(2):154-164. 
39. Team CW (2008) Synthesis report. Climate Change 2007. Working Groups I, II and III to the Fourth Assessment.

40. Das S, Bhattacharyya P, Adhya TK (2011) Interaction effects of elevated CO 2 and temperature on microbial biomass and enzyme activities in tropical rice soils. Environ Monitoring Assessment, 182(1):555-569.

41. Bhattacharyya P, Roy KS, Das M, Ray S, Balachandar D, Karthikeyan S, Nayak AK, Mohapatra T (2016) Elucidation of rice rhizosphere metagenome in relation to methane and nitrogen metabolism under elevated carbon dioxide and temperature using whole genome metagenomic approach. Sci Total Environ 542:886-898.

42. Wu Z, Dijkstra P, Koch GW, Peñuelas J, Hungate BA (2011) Responses of terrestrial ecosystems to temperature and precipitation change: A meta-analysis of experimental manipulation. Global Change Biol 17(2):927-942.

43. Savage K, Davidson EA, Richardson AD, Hollinger DY (2009) Three scales of temporal resolution from automated soil respiration measurements. Agri Forest Meteorol 149(11):2012-2021.

44. Suseela V, Conant RT, Wallenstein MD, Dukes JS (2012) Effects of soil moisture on the temperature sensitivity of heterotrophic respiration vary seasonally in an old-field climate change experiment. Global Change Biol 18(1):336-348.

45. Wang G, Post WM, Mayes MA (2013) Development of microbial-enzyme-mediated decomposition model parameters through steady-state and dynamic analyses. Ecological Applications 23(1):255-272.

46. Nottingham AT, Bååth E, Reischke S, Salinas N, Meir P (2019) Adaptation of soil microbial growth to temperature: Using a tropical elevation gradient to predict future changes. Global Change Biol 25(3):827-838.

47. Aanderud ZT, Jones SE, Schoolmaster Jr DR, Fierer N, Lennon JT (2013) Sensitivity of soil respiration and microbial communities to altered snowfall. Soil Biol Biochem 57:217-227.

48. Liu Y, He N, Wen X, Xu L, Sun X, Yu G, Liang L, Schipper LA (2018) The optimum temperature of soil microbial respiration: Patterns and controls. Soil Biol Biochem 121:35-42.

49. Easterling W, Apps M (2005) Assessing the consequences of climate change for food and forest resources: a view from the IPCC. In Increasing Climate Variability and Change (pp. 165-189). Springer, Dordrecht.

50. Wreford A, Ignaciuk A, Gruère G (2017) Overcoming barriers to the adoption of climate-friendly practices in agriculture.

51. Hutchins DA, Walworth NG, Webb EA, Saito MA, Moran D, Mcllvin MR, Gale J, Fu FX (2015) Irreversibly increased nitrogen fixation in Trichodesmium experimentally adapted to elevated carbon dioxide. Nature Communications 6(1):1-7.

52. Riebesell U, Aberle-Malzahn N, Achterberg EP, Algueró-Muñiz M, Alvarez-Fernandez S, Arístegui J, Bach LT, Boersma M, Boxhammer T, Guan W, Haunost M (2018) Toxic algal bloom induced by ocean acidification disrupts the pelagic food web. Nature Climate Change 8(12):1082-1086.

53. Schlesinger WH, Lichter J (2001) Limited carbon storage in soil and litter of experimental forest plots under increased atmospheric $\mathrm{CO}_{2}$. Nature, 411(6836):466-469. 
54. Stevnbak K, Scherber C, Gladbach DJ, Beier C, Mikkelsen TN, Christensen S (2012) Interactions between aboveand belowground organisms modified in climate change experiments. Nature Climate Change 2(11):805-808.

55. Vestergård M, Reinsch S, Bengtson P, Ambus P, Christensen S (2016) Enhanced priming of old, not new soil carbon at elevated atmospheric $\mathrm{CO}_{2}$. Soil Biol Biochem 100:140-148.

56. Norby RJ, Ledford J, Reilly CD, Miller NE, O'Neill EG (2004) Fine-root production dominates response of a deciduous forest to atmospheric $\mathrm{CO}_{2}$ enrichment. Proceedings of the national Academy of Sciences, 101(26):96899693.

57. Lewis SL, Lopez-Gonzalez G, Sonké B, Affum-Baffoe K, Baker TR, Ojo LO, Phillips OL, Reitsma JM, White L, Comiskey JA, Ewango CE (2009) Increasing carbon storage in intact African tropical forests. Nature, 457(7232):1003-1006.

58. Langley JA, McKinley DC, Wolf AA, Hungate BA, Drake BG, Megonigal JP (2009) Priming depletes soil carbon and releases nitrogen in a scrub-oak ecosystem exposed to elevated $\mathrm{CO}_{2}$. Soil Biol Biochem 41(1):54-60.

59. Schaum E, Rost B, Millar AJ, Collins S (2013) Variation in plastic responses of a globally distributed picoplankton species to ocean acidification. Nature Climate Change 3(3):298-302.

60. Walsh DA (2015) Consequences of climate changes on microbial life in the ocean. Microbiol Today (Nov 2015 issue). Microbiology Society, England.

61. Madhu M, Hatfield JL (2014) Interaction of carbon dioxide enrichment and soil moisture on photosynthesis, transpiration, and water use efficiency of soybean. Agri Sci.

62. Cavicchioli R, Ripple WJ, Timmis KN, Azam F, Bakken LR, Baylis M, Behrenfeld MJ, Boetius A, Boyd PW, Classen AT, Crowther TW (2019) Scientists' warning to humanity: microorganisms and climate change. Nature Rev Microbiol 17(9):569-586.

63. HoĖgberg P, Nordgren A, Buchmann N, Taylor AF, Ekblad A, HoÈgberg MN, Nyberg G, Ottosson-LoÈfvenius M, Read DJ (2001) Large-scale Forest girdling shows that current photosynthesis drives soil respiration. Nature, 411(6839):789-792.

64. Dijkstra FA, Prior SA, Runion GB, Torbert HA, Tian H, Lu C, Venterea RT (2012) Effects of elevated carbon dioxide and increased temperature on methane and nitrous oxide fluxes: evidence from field experiments. Frontiers Ecol Environ 10(10):520-527.

65. Bhattacharyya P, Roy KS, Neogi S, Dash PK, Nayak AK, Mohanty S, Baig MJ, Sarkar RK, Rao KS (2013) Impact of elevated $\mathrm{CO}_{2}$ and temperature on soil $\mathrm{C}$ and $\mathrm{N}$ dynamics in relation to $\mathrm{CH}_{4}$ and $\mathrm{N}_{2} \mathrm{O}$ emissions from tropical flooded rice (Oryza sativa L.). Sci Total Environ 461:601-611.

\section{Figures}




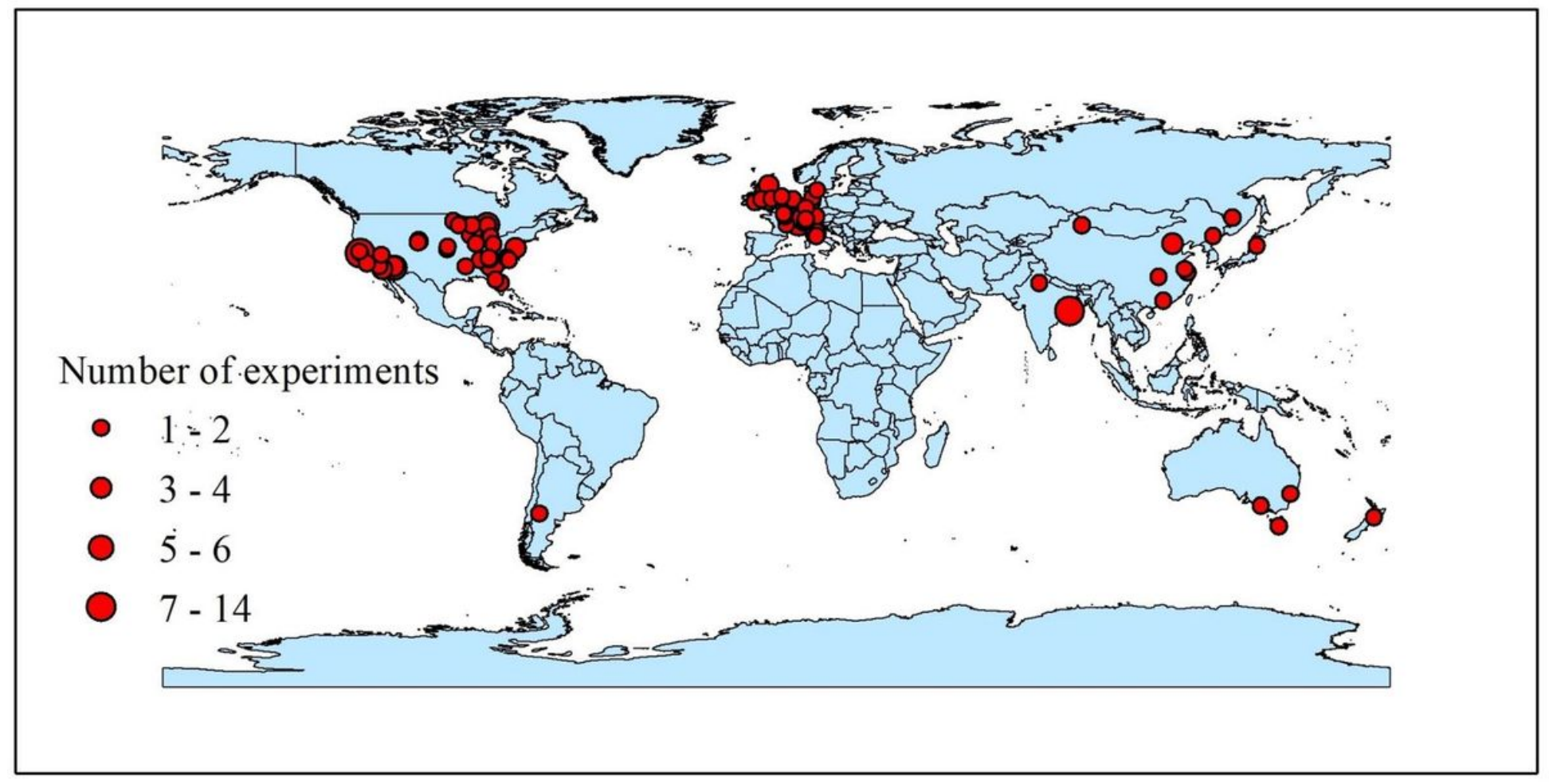

Figure 1

Spatial distribution of experimental sites considered for meta-analysis in the study. 

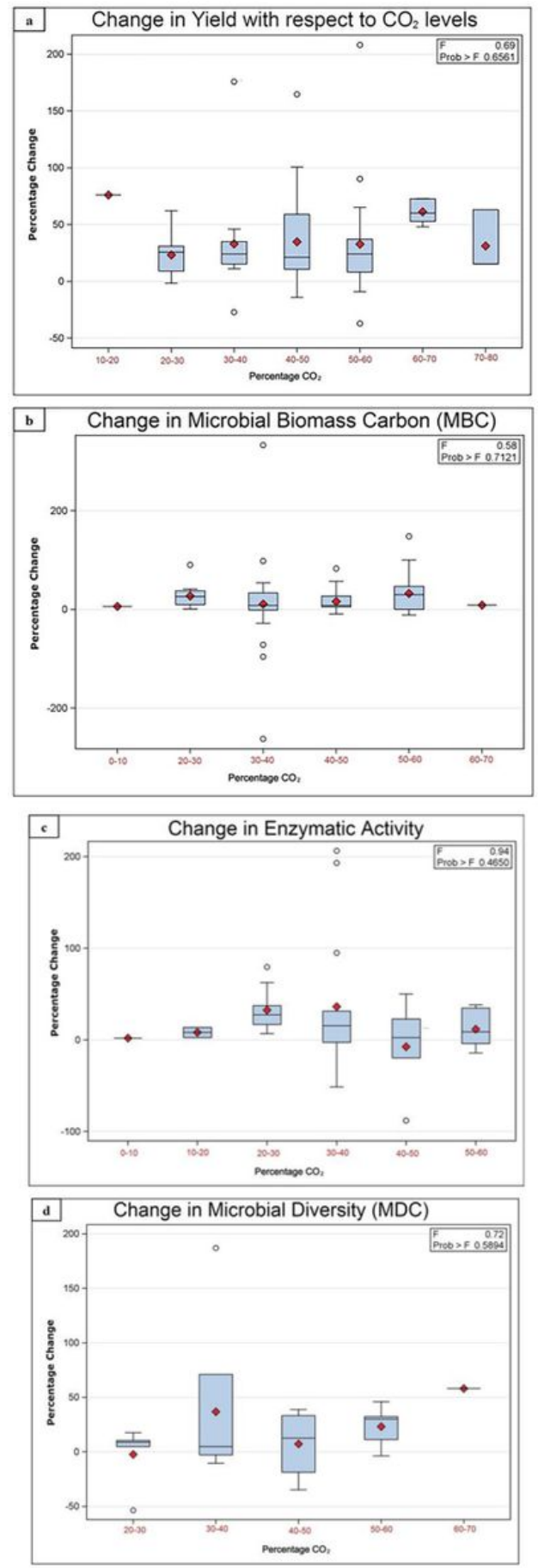

Figure 2

Changes of (a) Yield, (b) Microbial biomass carbon (MBC), (c) Soil enzymatic activities (d) Microbial diversity (MDC) at different CO2- elevation range. [Note: The summary statistic (mean, quartiles, minimum, maximum, and extreme observations/probable outliers) of measurements along with the F-value and Prob >F.] 

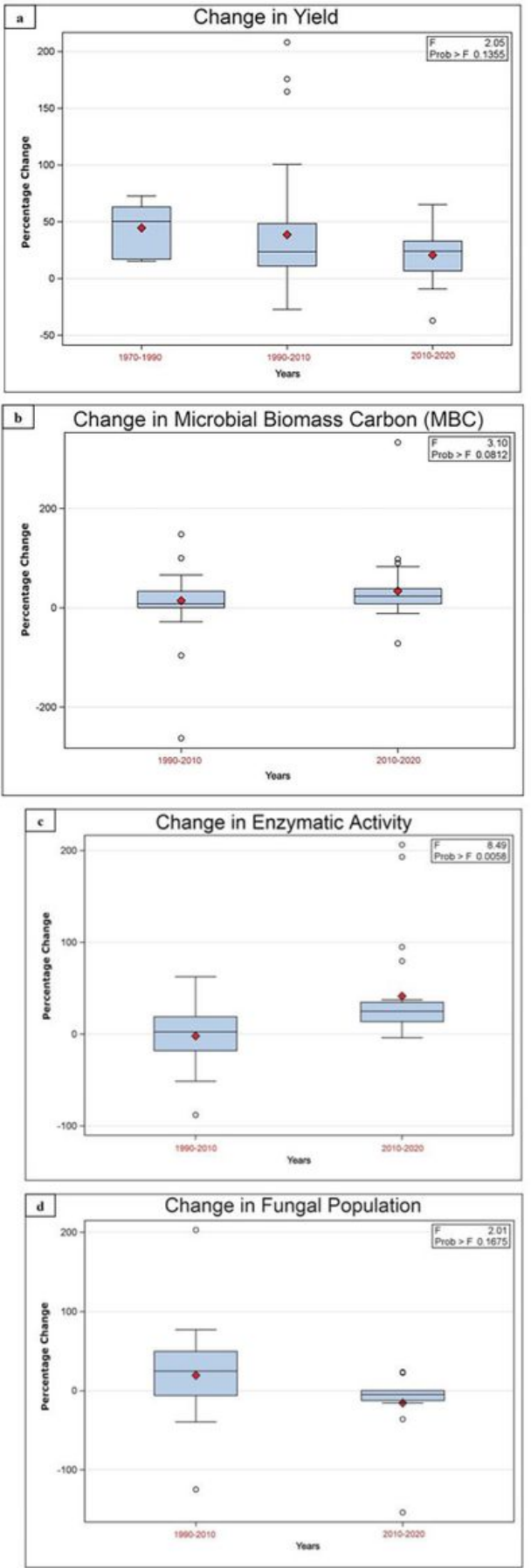

Figure 3

Changes of (a) yield, (b) Microbial biomass carbon (MBC), (c) Soil enzymatic activities and (d) Fungal population (FP) at temporal scale (1970-1989; 1990-1999; 2010-2020). [Note: The summary statistic (mean, quartiles, minimum, maximum, and extreme observations/probable outliers) of measurements along with the F-value and Prob $>$ F.] 

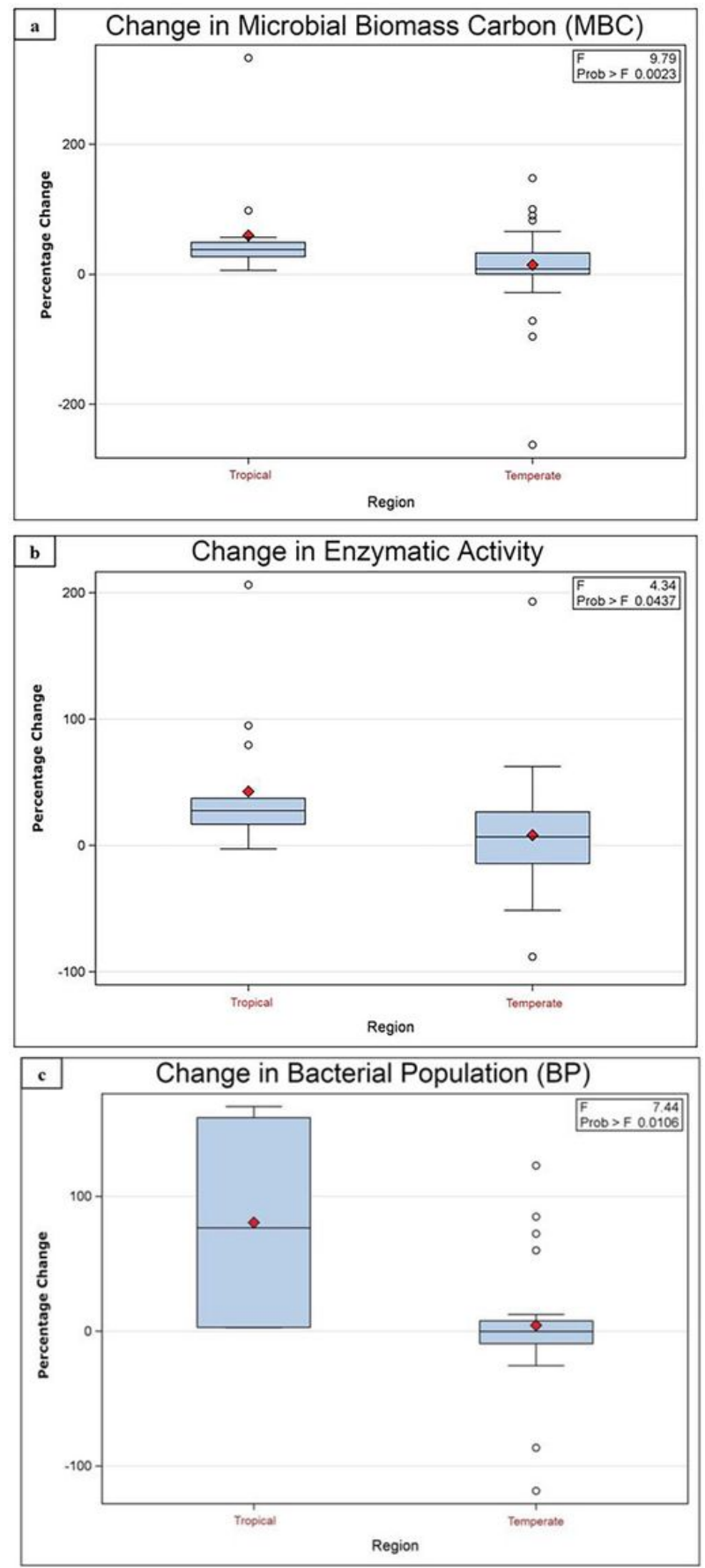

\section{Figure 4}

Changes of (a) Microbial biomass carbon (MBC), (b) Soil enzymatic activities and (c) Bacterial population (BP) in tropical and temperate region. [Note: The summary statistic (mean, quartiles, minimum, maximum, and extreme observations/probable outliers) of measurements along with the F-value and Prob >F.] 


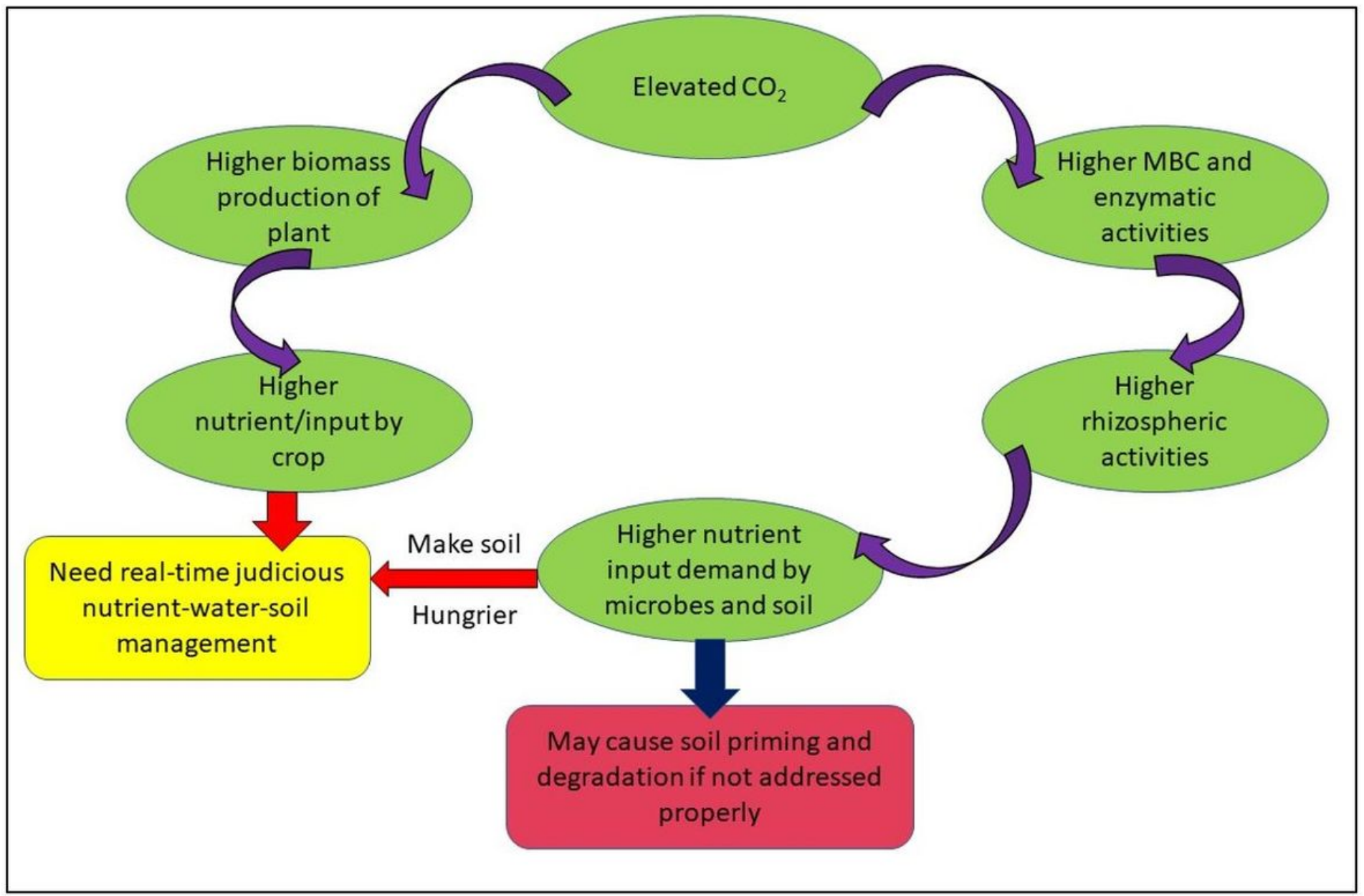

\section{Figure 5}

Conceptualization the impact of elevated $\mathrm{CO} 2$ on crop yield and microbial diversities.

\section{Supplementary Files}

This is a list of supplementary files associated with this preprint. Click to download.

- supplementary.docx 